\title{
TITLE:
}

\section{CAPRELLIDS FROM KAMAE BAY, NORTHEASTERN KYUSYU (AMPHIPODA : CAPRELLIDAE)}

\author{
$\operatorname{AUTHOR}(\mathrm{S})$ : \\ Utinomi, Huzio
}

\section{CITATION:}

Utinomi, Huzio. CAPRELLIDS FROM KAMAE BAY, NORTHEASTERN KYUSYU (AMPHIPODA: CAPRELLIDAE). PUBLICATIONS OF THE SETO MARINE BIOLOGICAL LABORATORY 1969, 16(5): 295-306

\section{ISSUE DATE:}

1969-01-31

URL:

http://hdl.handle.net/2433/175557

RIGHT: 


\title{
CAPRELLIDS FROM KAMAÉ BAY, NORTHEASTERN KYUSYU (AMPHIPODA : CAPRELLIDAE) $)^{12}$
}

\author{
Huzio UTINOMI \\ Seto Marine Biological Laboratory, Sirahama
}

With 5 Text-figures

This paper deals systematically with a small collection of skeleton shrimps obtained during a biological survey of the reef coral-inhabiting area in Kamaé Bay, a small inlet located on the coast of Oita Prefecture, northeastern Kyusyu where hermatypic corals are luxuriantly thriving. The survey was carried out under the collaboration of the Seto Marine Biological Laboratory of the Kyoto University and the Oita Ecological Aquarium (Director: Mr Kunio Horike) on July 17-21 th, 1965. The survey was undertaken only from the ecological standpoint at a limited scale, and thus no extensive faunistic investigation was made.

Among the meiobenthic organisms obtained in this survey, the following caprellids were discriminated at two stations.

1) Suno-hana, a sand-bar located at the northwest cape of Yakata-sima, mouth of Kamaé Bay, $3 \mathrm{~m}$ deep, where Sargassum serratifolium C. Agardh and S. tortile G. AgARdh are dominant.

Hemiaegina minuta MAYER 1 令

Aciconula miranda MAYER 1 우

Caprella danileuskii Czerniavsky 7 $\delta, 2$ 우

C. decipiens MAYER 3个昘, 1 우

C. polyacantha UTINomi $2 \hat{\delta} \hat{\delta}$

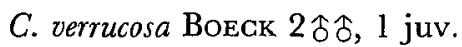

2) Morisaki, Huka-sima, southwest of the outside of Kamaé Bay, $4 \mathrm{~m}$ deep, where Sargassum duplicatum J. Agardh and Caulerpa racemosa Weber. van Bosse grow. Caprella drepanochir MAYER $2 \hat{\delta} \hat{\delta}, 1$ ㅇ

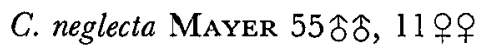

C. scaura diceros MAYER 2송, 3 우우

C. verrucosa BoEck 4송ㅇㅇ, 2 우우

1) Biological studies of the reef coral areas of Japanese Main Islands, No. 3.

2) Contributions from the Seto Marine Biological Laboratory, No. 498 and also Contribution No. 15 from the Oita Ecological Aquarium.

Publ. Seto Mar. Biol. Lab., XVI (5), 295-306, 1969. (Article 22) 
On this occasion, I am grateful to the other members of the surveying party for their pertinent field work, especially to Dr T. TокıокA for his effort in collecting and sorting of samples.

\section{Aciconula miranda MAYER}

(Jap. name: Higeasi-warekara, nov.)

(Fig. 1)

Mayer, 1903, p. 43, pl. 6, figs. 64-67; pl. 9, figs. 8 and 33; pl. 10, fig. 10; MaYer, 1912, p. 10, fig. 4 .

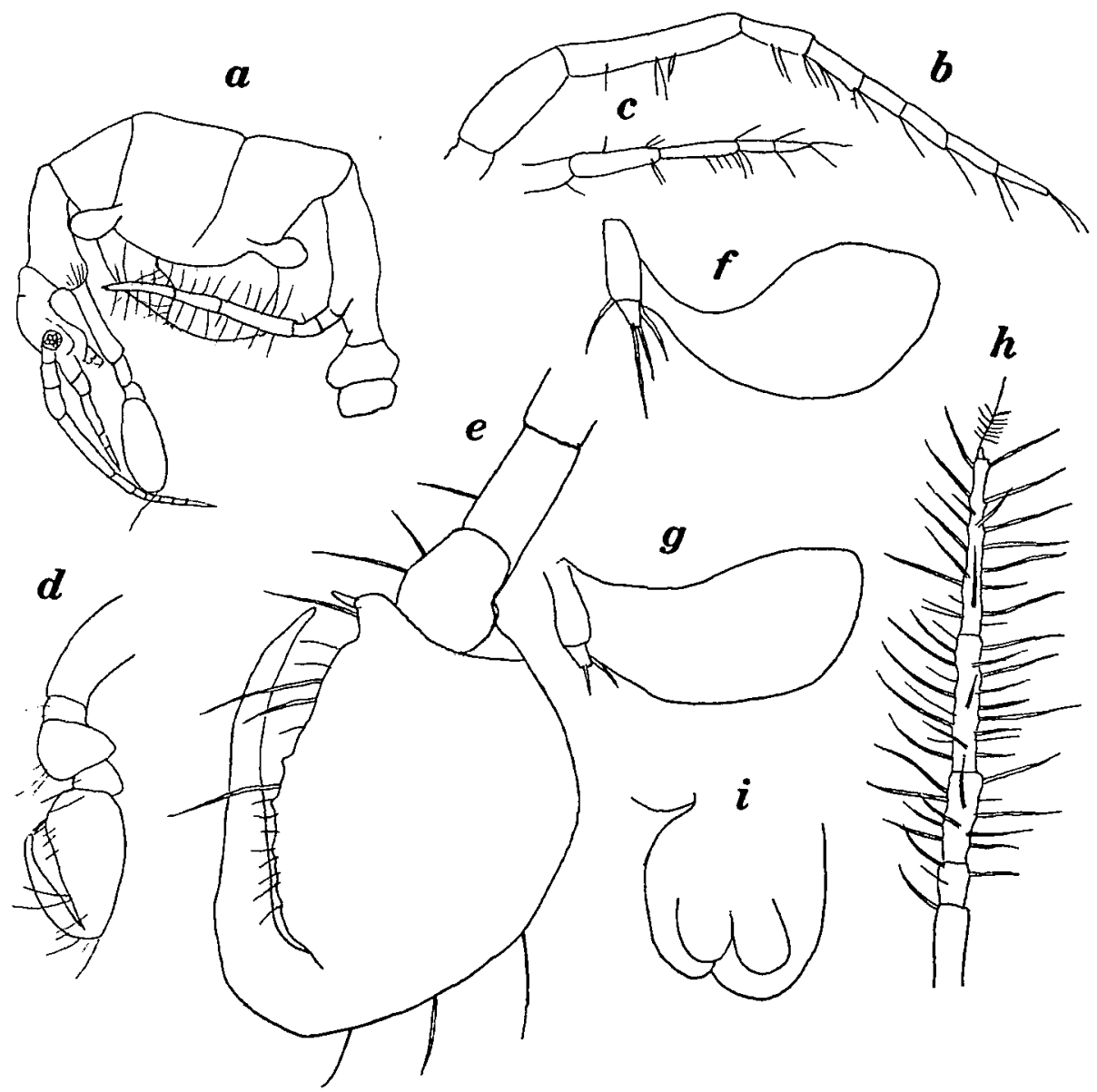

Fig. 1. Aciconula miranda MAYER. +

$a$, Lateral aspect $(\times 32) . \quad b$, Antenna $1(\times 80) . \quad c$, Antenna $2(\times 80) . \quad d$, Gnathopod $1(\times 150)$.

$e$, Gnathopod $2(\times 150)$. $f$, Pereopod 3 with gill $(\times 150) . \quad g$, Pereopod 4 with gill $(\times 150)$.

$h$, Pereopod $5(\times 80)$. i, Abdomen $(\times 150)$. 
Material.- 1 ․ Sunohana, Yakata-sima, 3 m. 19-VII-1965.

Description. - Body length $3 \mathrm{~mm}$.

Head smooth, longer than pereonite 1, fused by a transverse suture. Pereonite 2 smooth, lacking such a dorsal spine as figured originally, though triangular in lateral aspect, being projecting anteroventrally at the attachment of gnathopod 2. Pereonites 3 and 4 subequal in length, rather plump, with a small oval gill and 2-jointed rudimentary pereopod respectively. Pereonite 5 slender, a little longer than pereonite 4, having well-developed hairy pereopod 5. Pereonites 6 and 7 much shorter than preceding pereonites. Abdomen small, with a pair of pleopods, simply lobed.

Antenna 1 approximately a half of body length; peduncle 4-jointed, plump, weakly setose; flagellum of 6 joints. Antenna 2 approximately as long as peduncle of antenna 1 ; flagellum of 2 joints shorter than 2 -jointed peduncle; both weakly setose as in antenna 1.

Gnathopod 1 small; hand triangular, quite setose, with 2 proximal grasping spines. Gnathopod 2 well-developed, attached to triangular projections on fore-end of pereonite 2; basal articles long, smooth; propodus roughly oval, with 2 grasping spines on a proximal projection; palmar margin slightly convex and indented and strongly setose; dactylus broad, with its inner margin evenly concave, not serrate.

Gills generally small, oval, narrow-necked. Pereopods 3 and 4 attached to base of gills rudimentary, but clearly 2 -jointed.

Pereopod 5 abnormal in caprellids, long, soft and flexible; distal 4 or 5 articles conspicuously hairy and forwardly directing in situ, and thus easily detachable. Pereopods 6 and 7 missing.

Remarks. - This unique species is hitherto known only of 2 females obtained at Singapore, 5-6 fathoms in 1899 and at Koh Krau (Bay of Thailand), 30 fathoms in 1900 , and then 1 male and 2 females in Sharks Bay, southwest Australia, 11-16 m in 1905. Thus, the record of occurrence in shallow waters of Kamaé Bay northwards may deserve special attention.

\section{Hemiaegina minuta MAYER}

(Jap. name: Hime-warekara, nov.)

(Fig. 2)

Hemiagina minuta MAYeR, 1890, p. 40, pl. 1, figs. 25-27, pl. 3, figs. 32-35, pl. 5, figs. 52-53, pl. 6, figs. 13, 33 and 34, pl. 7, fig. 4 (15 miles off Amoy, 8-25 fms); MAYER, 1903, p. 65, pl. 6, fig. 72 (Siboga St. $164,1^{\circ} 42.5^{\prime} \mathrm{S}, 130^{\circ} 47.5^{\prime} \mathrm{E}$, south of Salawatti, $32 \mathrm{~m}$, sand bottom); Arimoto, 1930, p. 45 (13), fig. 2 (Tateyama, on Sargassum); Barnard, 1937, p. 198 (South Arabian coast); Utinomi, 1947, p. 70 (no new record); Edmondson and Mansfield, 1948, p. 206, fig. 3 (Waikiki Reef, Oahu Is., on Plumurarian hydroids); Steinberg and Dougherty, 1957, p. 281, figs. 8-11, 13 and 29 (Port Aransas, Texas); Utinomi, 1964, p. 14 (Nomosaki, Nagasaki-ken, Kyusyu); McCAIN, 1965, p. 192 (Virginia, N. America).

Hemiaegina quadripunctata Sundara RAJ, 1927, p. 125, pl. 18, figs. 1-7 (Krusadai Is., Gulf of Manaar). 
Material.-1 1 . Sunohana, Yakata-sima, 3 m. 19-VII-1965.

Description.- Body $3 \mathrm{~mm}$ long, smooth, slender and slightly expanded on both sides at base of attachment of all pereopods.

Head about three times as long as pereonite 1 closely fused with slight suture; fore end roundly angled; eyes small. Pereonite 2 slightly shorter than head + pereonite 1. Pereonites 3 and 4, each with elongate gill and rudimentary pereopod, subequal in length and approximately as long as pereonite 2. Pereonite 6 longest and pereonite 7 shortest.

Last abdomen small but characteristic, a pair of digitiform 2-jointed, long pleopods being exceedingly protruding posteriorly.

Antenna 1 about $2 \mathrm{~mm}$ long, 13-jointed and feebly setose. Antenna 2 about a

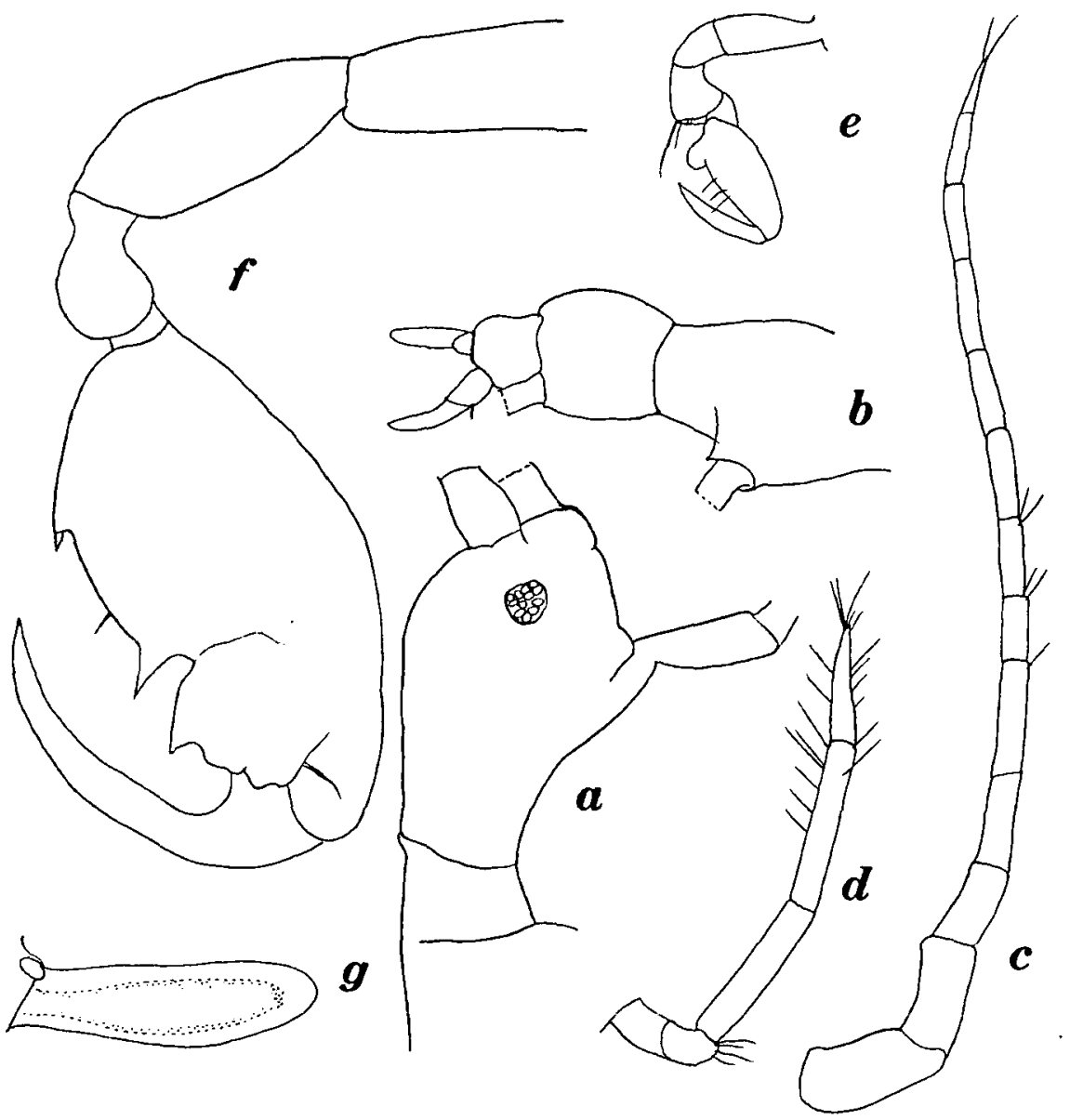

Fig. 2. Hemiaegina minuta MAYER. o

$a$, Head, lateral aspect. $\quad b$, Terminal part of body and abdomen with pleopods, lateral aspect. $c$, Antenna 1. d, Antenna 2. e, gnathopod 1. $f$, Gnathopod 2. $g$, Gill and pereopod 3.

$($ All $\times 80)$ 
half as long as antenna 1, with 2-jointed flagellum.

Gnathopod 1 small, with a peculiar semicircular pad at proximal end of straight palm, as figured by MAYER (1890, pl. 7, fig. 4). Gnathopod 2 exceedingly large; propodus also peculiar with a profoundly expanded and bluntly indented distal projection as a hingepoint of dactylus, followed by a wide squarish notch and a pointed median tooth on palm; grasping spines small, submedial; apparently not setose in all articles.

Gills 1 and 2 attached to center of pereonites 3 and 4 elongate, bearing at their bases very minute pereopods as rudimentary bud.

Posterior pereopods 5-7 lacking.

Distribution.- As cited above, this species is widely distributed in all temperate and tropical coastal waters.

\section{Caprella danilevskii CZERNIAVSKY}

(Jap. name: Hoso-warekara Utn.)

For synonymy, description and references see HiRo, 1937, p. 312, pl. 22, fig. 6.

Material.— 7ㅅํㅇ, 2 우. Sunohana, Yakata-sima, 3 m. 19-VII-1965.

Distribution. - Cosmopolitan.

\section{Caprella decipiens MAYER}

(Jap. name: Magire-warekara, nov.)

(Fig. 3)

MAYer, 1890, p. 86, pl. 7, figs. 37-40 (Kadsiyama*); Arimoto, 1930, p. 51 (19), fig. 6 (Tateyama, on Sargassum); Hiro, 1937, p. 313, pl. 22, fig. 7 (Tanabe Bay); Utinomi, 1947, p. 73 (Tomioka and Mukaisima); Utromom, 1964, p. 14 (Tomioka).

Material.- 3今ई, 1 ㅇ. Sunohana, Yakata-sima, 3 m. 19-VII-1965.

Description.- Body smooth, slender, up to $4 \mathrm{~mm}$ long in both sexes. Head rightangled at fore end, with somewhat large eyes on either side just beneath fore angle. Pereonite 1 fused with head approximately half as long as head. Pereonites 2-5 elongate, subequal in length. Pereonites 6 and 7 shorter than each of preceding ones and subequal in length, the sum being about the same as pereonite 5 .

Antenna 1 characteristic, 2 basal articles of peduncle being very stout, a little longer than a half the whole length, and a distal article of peduncle very short, as slender as multiarticulated flagellum. Antenna 2, as long as peduncle of antenna 1, strongly setose on lower margins.

Gnathopod 1 small. Gnathopod 2 attached near fore end of pereonite 2; basal

* Truly Katsuyama, north of Tateyama, entrance to Tokyo Bay, Japan. 


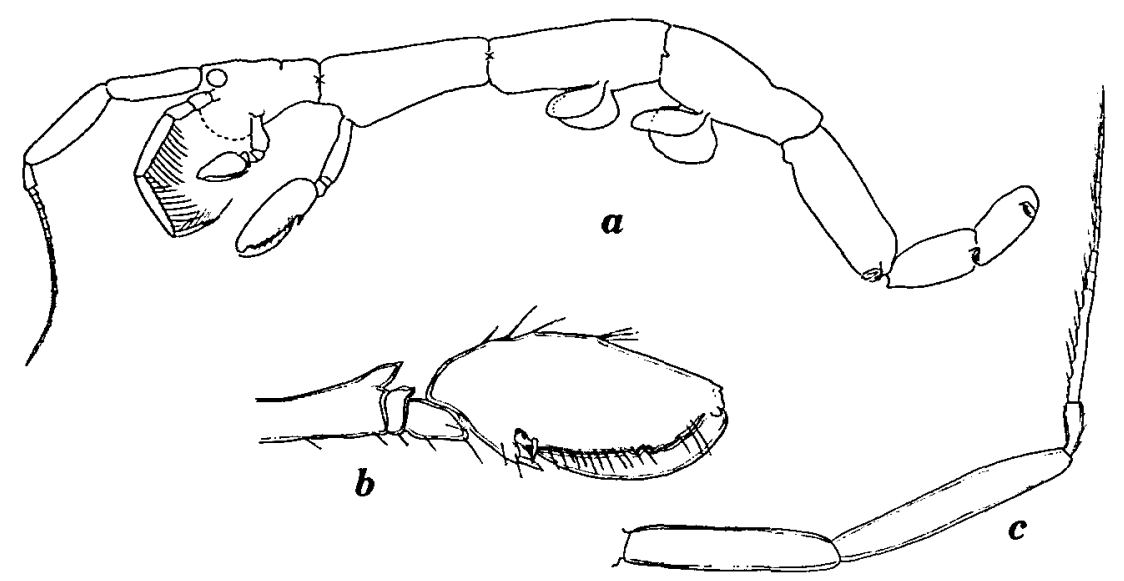

Fig. 3. Caprella decipiens MAYkR. $\$$ $a$, Lateral aspect $(\times 25) . \quad b$, Gnathopod $2(\times 85)$. c, Antenna $1(\times 112)$.

article a little shorter than a half of pereonite 2, terminating into a strong spine on fore margin; propodus elongate, setose on fore and hind margins; palmar margin slightly convex with 2 rudimentary poison teeth submedially and a pair of grasping spines close to a spine-bearing proximal projection.

Gills 1 and 2 small, oval and bent forward.

Pereopods 5-7 normal, with a pair of dentate grasping spines proximally on palmar margin of propodus.

Distribution.-From previous records it is deduced to be endemic to temperate coastal waters of Japan, like $C$. subinermis MAYER, one of the relatives, as is suggested by the specific name decipiens which means to be deceived for $C$. subinermis. But, both, often occurring together, can easily be differentiated by the peculiarity shown in the proportional size of articles between the peduncle and flagellum of the first antenna. C. danilevskii mentioned above is also allied to both species.

\section{Caprella drepanochir MAYER}

(Jap. name: Togeasi-warekara, nov.)

(Fig. 4)

MAYER, 1890, p. 81, 7, figs. 15, 33 and 34 ("Reise von China nach der Amurmündung"); MAYER 1903, p. 100, pl. 4, fig. 11 (Wladywostok; Bering Island; Chamisso Harbour, Eschscholtz Bay, 5-8 fms, sand); Urinomi, 1943c, p. 289, figs. 5-6 (Akkeshi Bay, 1 m); Urnom, 1947, p. 73 (no new record).

Material.-2\}ิ, 1 우. Morisaki, Huka-sima, SW of Kamaé Bay, 4 m. 18-VII1965.

Description.- Approximately $8-10 \mathrm{~mm}$ in body length. Body smooth, moderately plump, devoid of tubercles or spines. 
Head nearly as long as pereonite 1; fore end only bluntly angled; eyes rather small. Pereonites 2-5 as long as cephalon and subequal in length. Each of pereonites 6-7 about a half of preceding pereonite or less.

Antenna 1 nearly $1 / 3$ of body length; peduncle 3 -jointed, each article being sub-

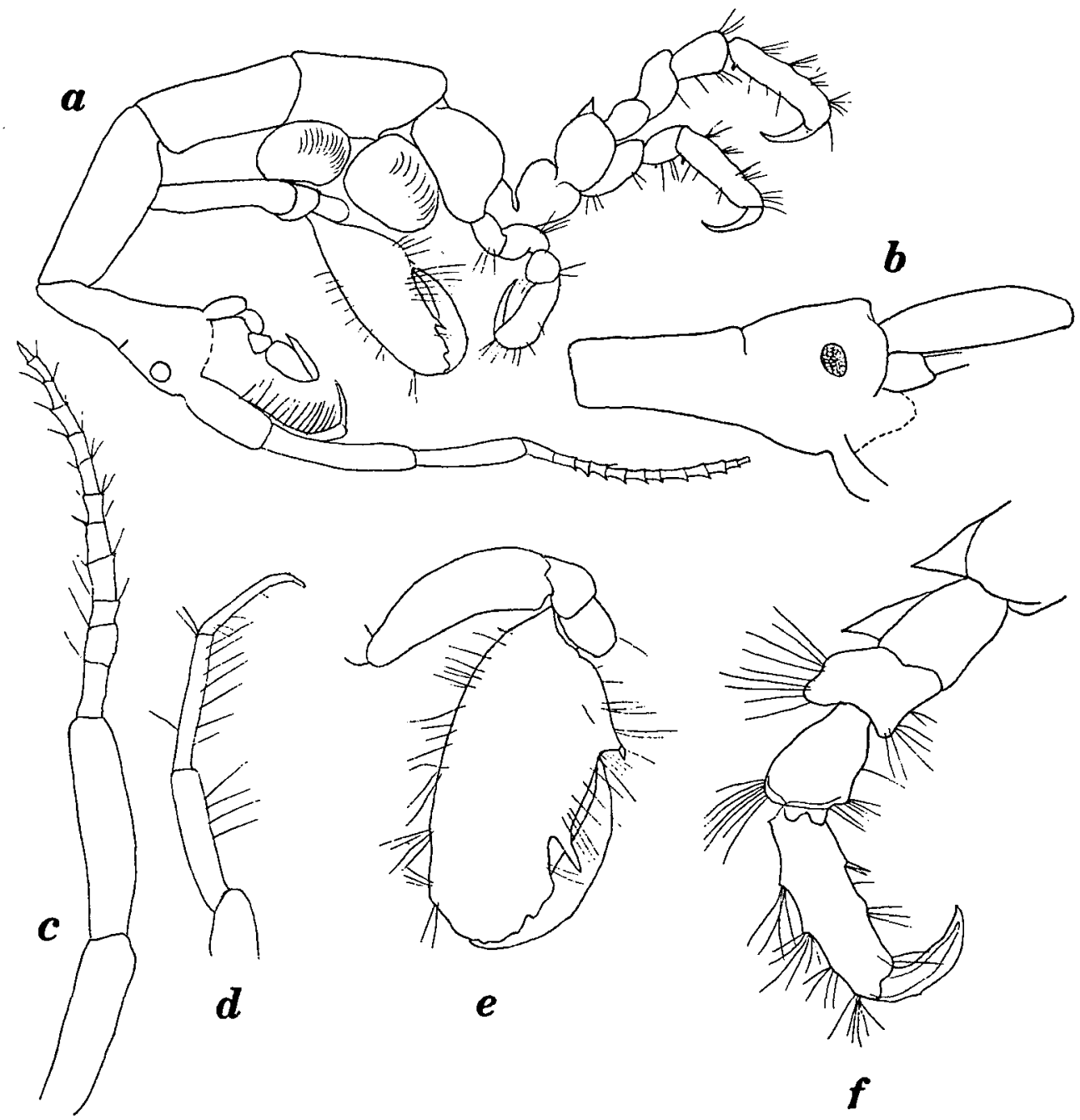

Fig. 4. Caprella drepanochir MAYER. o

$a$, Lateral aspect $(\times 13) . \quad b$, Head and pereonite 1 , lateral aspect $(\times 32) . \quad c$, Antenna $1(\times 32)$. $d$, Antenna $2(\times 32)$. e, Gnathopod $2(\times 32)$. $f$, Pereopod $7(\times 32)$.

equal in length or nearly so, elongate and plump; flagellum 12-jointed, each article being short and slender. Antenna 2 a little longer than peduncle of antenna 1, 4 or 5 -jointed, with swimming setae arranged on lower margin. 
Gnathopod 1 small. Gnathopod 2 large, with basal article about a half as long as pereonite 2 ; propodus large, strongly setose; palm slightly concave, with a sharp poison tooth submedially or subdistally between a small spine-bearing proximal projection and a distal broad expansion obscurely indented marginally; dactylus strong, closely fitted to palmar margin, with plain inner margin without serration.

Gills attached to pereonites 3-4 large and round (instead of 'klein, oval, platt' as MAYER originally described).

Pereopods 5-7 normal, robust and strongly setose; hind margin of 3 basal articles with a triangular outgrowth distally; in addition on the 5th article (carpus) there are 2-3 blunt teeth on inner distal margin; the 6th article (propodus) quadrangular, adorned with 4-5 blunt teeth, each bearing a tuft of long setae on hind margin and a pair of proximal grasping spines and a number of similar setae on fore margin; dactylus stout but rather short, being a little longer than a half of propodus.

Remarks. - This specimens here examined as well as those from Akkeshi Bay (UTіломі, 1943c) closely resemble the same named species from 3 northern localities (MAYER, 1903), but do not agree so closely with MAYER's original description (1890) in the outline of gills. If the apparent disagreement is proved not to be due to the difference in growth or the condition of preservation, this may be turned to an undescribed relative.

\section{Caprella neglecta MAYER}

(Jap. name: Maruera-warekara Utn.)

Caprella acutifrons Latreille.-MAyer, 1882, pp. 48-50; Schellenderg, 1938, p. 95 (Oahu, Hawaii); Edmondson and Mansfield, 1948, p. 212, fig. 6 (Hawaii); Irie, 1958a, p. 107 (Omura Bay); IrIE, 1958b, p. 91 (Sasebo Bay).

C. acutifrons var. (or forma) natalensis MAYER.-ARimoto, 1930, p. 48 (16), fig. 3 (Tateyama); Hiro, 1937, p. 312, pl. 22, fig. 5 (Tanabe Bay).

C. acutifrons var. (or forma) neglecta MAYER, 1890, p. 55, pl. 2, fig. 37, pl. 4, figs. 67-68; MAYER, 1903, p. 80; Utinomi, 1943c, p. 284, fig. 1 (Osyoro, Hokkaido); Utinomi, 1947, p. 72 (many records of occurrence in Japan); UTiNomi, 1964, p. 14 (Tomioka).

C. neglecta MAYer.-VAssilenko, 1967, p. 200, figs. 5-6 (Possjet Bay).

Material.- 55今ో, 11 우우. Morisaki, Huka-sima, 4 m. 18-VII-1965.

Distribution. - Most abundant all around the oriental region and Hawaiian Islands.

\section{Caprella polyacantha UTINOMI}

(Jap. name: Iga-warekara, nov.)

(Fig. 5)

Utinomi, 1947, p. 75, figs. 4-5 (Asamusi, Aomori Bay); Vassilenko, 1967, p. 203, gs. 7-8 (Possjet Bay, Sea of Japan). 
Material.-2ઈઈ. Sunohana, Yakata-sima, 3 m. 19-VII-1965.

Description.- Body $4 \mathrm{~mm}$ long, covered with many thorny spines arranged in 4 or 5 longitudinal rows all throughout from head to end of body.

Head not pointed at fore end, short, as long as wide, completely fused with pereonite 1 without any suture; eyes rather large.

Pereonites 2-4 subequal in length, much more than head + pereonite 1. Pereonite 5 shorter than pereonite 4 , but longer than either of pereonites 6 and 7 .

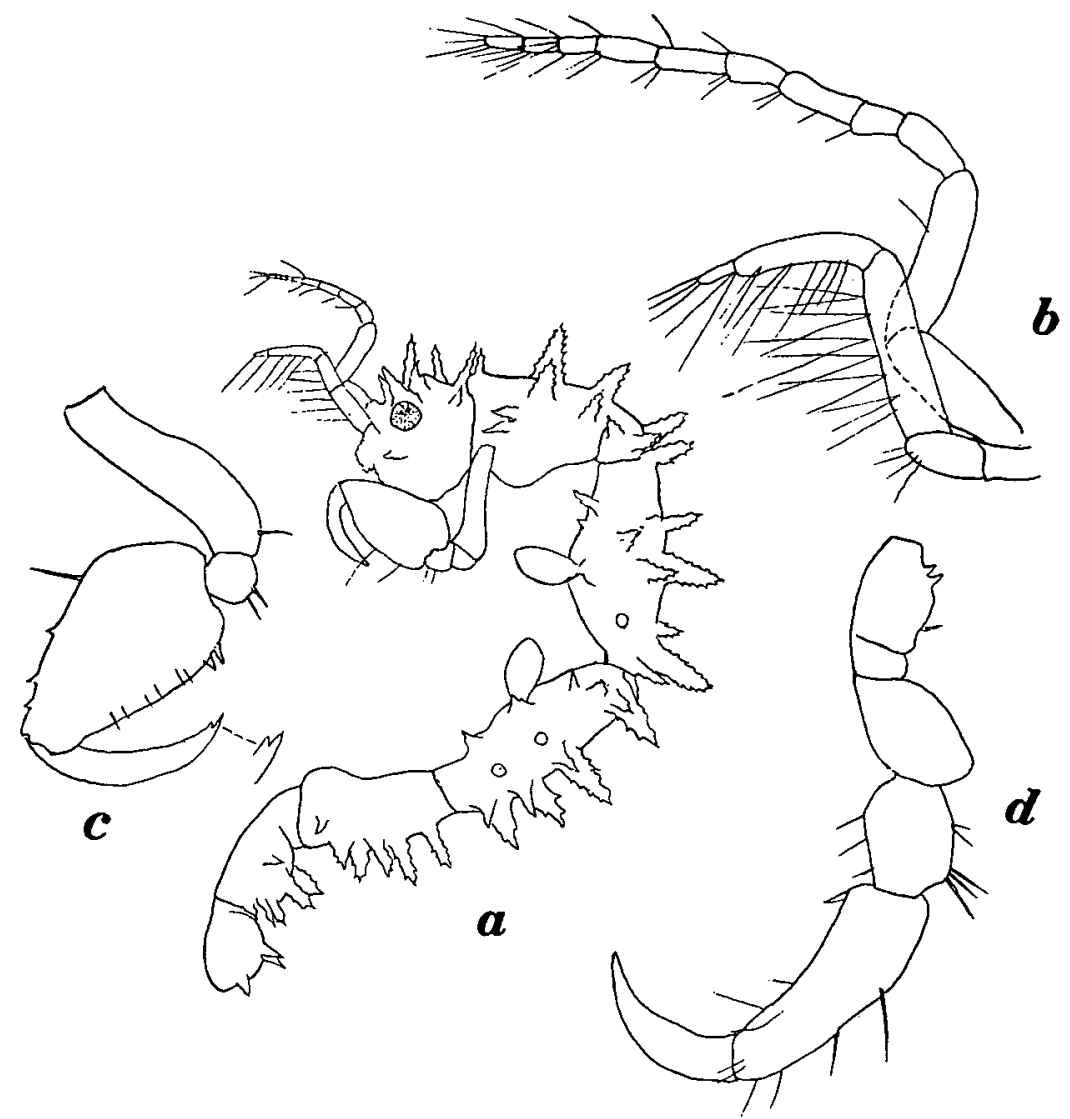

Fig. 5. Caprella polyacantha UTiNomi. o

$a$, Lateral aspect $(\times 33) . \quad b$, Antennae 1 and $2(\times 63) . \quad c$, Gnathopod $2(\times 63)$. $d$, Pereopod $5(\times 63)$.

Antenna 1 approximately shorter than a half of body length, consisting of 3jointed peduncle and 7- or 8-jointed flagellum, bearing each a few setae distally. Antenna 2 slightly longer than peduncle of antenna 1; flagellum 3-jointed, longly setose ventrally.

Gnathopod 1 small. Gnathopod 2 attached to near fore end of pereonite 2; 
propodus about as long as basal article roughly triangular with denticulate, convex fore margin and slightly concave palmar margin bearing 2 grasping spines proximally, distal projection being indistinct, lacking any poison tooth medially; dactylus strong, with slightly serrate inner margin bifurcated at end.

Gills on pereonites 3 and 4 rather small, oval in outline. In pereopods 5-7, hind margins of basis and merus denticulate, carpus pentagonal in outline, propodus quadrangular, tapered distally, with a pair of grasping spines proximally and dactylus shorter than propodus.

Distribution.- Hitherto known only from Aomori Bay, northern Honsyu and Possjet Bay, northwestern coast of the Sea of Japan.

\section{Caprella scaura diceros MAYER}

\section{(Jap. name: Toge-warekara Iwasa)}

Caprella scaura Templeton.-Stebing, 1888, p. 1257, pl. CXLIV (off Kobe, 50 fms, sand bottom); Arimoto, 1931, p. (16), pl. III, figs. 1-6 (Tateyama); Edmondson and Mansfield, 1948, p. 210 , fig. 5 (Hawaii).

C. scaura forma diceros MAYER, 1890, pp. 70-71, pl. 4, figs. 40-42, pl. 7, figs. 35-36; MAYER, 1903, p. 118; Hiro, 1937, p. 315, fig. 3, pl. 22, figs. 11-12 (Tanabe Bay, on Bugula and Sargassum); UTinomi, 1943a, p. 279 (Onagawa Harbour); Uтімомi, 1943b, p. 285, fig. 5 (Asamusi); Utinomi, 1947, p. 77 (many records from Japan); IrIE, 1958a, p. 107 (Omura Bay); UTiNomi, 1964, p. 14 (Tomioka, abundant on rafts for culture of pearl oysters, in Zostera belt and Sargassum belt).

C. scaura diceros Mayer.-VAssilenko, 1967, p. 211, gs. 11-12 (Prossjet Bay).

Material.-2\}ઈ, 3우우. Morisaki, Huka-sima, 4 m. 21-VII-1965.

Distribution.- Very common all along the oriental coasts.

\section{Caprella verrucosa BoECK}

(Jap. name: Kobu-warekara, nov.)

Caprella verrucosa BoEck, 1872, p. 38 (California); MAYER, 1882, p. 69; MAYER, 1890, p. 73; Dougherty and Steinberg, 1953, p. 47 (California).

C. acutifrons forma verrucosa MAYER, 1903, p. 83, pl. 3, figs. 17-19 (Misaki and Yokohama); ARrmoto, 1930, p. 49 (17), fig. 4 (Tateyama); UtıNomi, 1943a, p. 274, figs. 2B and 3B (Izusima in Onagawa Bay); Utinomi, 1947, p. 72; Utinomi, 1964, p. 14, pl. 1, fig. 2 (Tomioka).

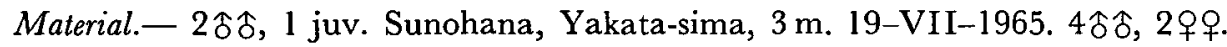
Morisaki, Huka-sima, 4 m. 18-VII-1965.

Remarks and distribution.- Formerly I have treated this species as a variety of $C$. acutifrons LATREILle, following MAYER's later procedure in classification, as in the case of $C$. neglecta. Indeed, it resembles very closely the relatives of $C$. acutifrons but it is distinguishable by having broad and obtuse dorsal tubercles whose typical arrangement is: $\mathrm{pn}_{1}-1$ or $0, \mathrm{pn}_{2}-2, \mathrm{pn}_{3}-3, \mathrm{pn}_{4}-3, \mathrm{pn}_{5}-3, \mathrm{pn}_{6}-1$ or $2, \mathrm{pn}_{7}-1$ in pairs and in having smaller (either round or oval) gills than those of $C$. acutifrons or neglecta. 
In addition, the palm of gnathopods 2 in overgrown specimens tends to become somewhat convex and much setose and to obsolete the poison tooth and grasping spines which are normally proximal in $C$. acutifrons or neglecta. MAYER at first doubted its specific validity, as referring it to $C$. acanthifera LEAGH juv. and then to $C$. septentrionalis KRÖYER, although the latter two are at present admitted as distinct species separately. Taking into consideration its morphological and ecological resemblances to the relatives, it seems best to treat it as a valid 'species' for the present, as is also the case of MAYER's formae borealis (cf. UTINOMI, 1943c., p. 287) and cristibrachium (cf. VASSILENKo, 1967, p. 197), both of which have been treated by MAYER (1903) as variants of $C$. acutifrons.

Hitherto known only from Japan and California, accordingly showing the amphi-North-Pacific distribution.

\section{REFERENCES}

Arimoto, I. 1929. Studies on the Caprellidae from Tateyama. Hakubutu-Gakkaisi (=Hakubutugaku Zassi), vol. 27, no. 38, pp. (1)-(12), pl. I, (In Japanese)

- 1930. Ditto. 2. Ibid., vol. 27, No. 39, pp. 45 (13)-56 (24), pl. II. (In Japanese)

1931. Ditto. 3. Ibid., vol. 28, No. 41, pp. 10-19, pl. III. (In Japanese)

Barnard, K. H. 1937. Amphipoda. Sci. Repts. John Murray Exped., vol. IV, No. 6, pp. 131-201.

Bовск, Axel 1872. Bidrag til Californiens Amphipodefauna. Särskilt Aftryk af Forhandlingen i Vidensk. Selskabet i Christiania aar 1871, pp. 32-51, 1 pl.

Chevreux, Ed. et L. Fage 1925. Amphipodes. Faune de France, 9, pp. 1-488. Paul Lechevalier, Paris.

Dovgherty, E.C. and Joan E. Steinberg 1953. Notes on the skeleton shrimps (Crustacea: Caprellidae) of California. Proc. Biol. Soc. Wash., Vol. 66, pp. 39-50.

- 1954. Key to the Caprellidae of California. In: Intertidal invertebrates of the central California. Univ. California Press, pp. 168-171.

Edmondson, C.H. and G.S. Mansfield 1948. Hawaiian Caprellidae. Occ. Pap. Bernice P. Bishop Mus., vol. XIX, No. 10, pp. 201-218.

Hiro, F. 1937. Caprellids from Tanabe Bay. Annot. Zool. Japon., vol. 16, No. 4, pp. 311-317, pl. 22.

Hirosaki, Y. 1964. Ecological study on fishes with drifting sea weeds. III. Accompanying animals excluded fishes. Misc. Rep. Res. Inst. Nat. Res., No. 62, pp. 63-70. (In Japanese)

IRIE, H. 1957. Pelagic amphipods in the western seas of Kyusyu. Bull. Fac. Fish., Nagasaki Univ., No. 5, pp. 41-52.

- 1958a. Pelagic amphipods in Omura Bay. Ibid., No. 6, pp. 106-108.

1958b. Vertical occurrences of pelagic amphipods in neritic and inshore waters in the neighborhood of Sasebo. Ibid., No. 7, pp. 87-92. (Caprellidae: 68)

1959. Studies on pelagic amphipods in the adjacent seas of Japan. Ibid., No. 8, pp. 19-42.

Mayer, P. 1882. Caprelliden. Fauna und Flora Golfes von Neapel, Mon. VI, pp. 1-157, pls. 1-10. Leipzig.

- 1890. Nachtrag zu den Caprelliden. Ibid., Mon. XVII, pp. 1-157, pls. 1-7. Berlin.

- 1903. Die Caprellidae der Siboga Expedition. Siboga-Expeditie, Mon. 34, pp. 1-160, pls. 110. Leiden.

1912. Caprellidae. Fauna Südwest-Australiens (W.Michaedsen und R. HARTMEyer, Herrausgegeb.), Bd. 4, Lief. 1, pp. 1-14.

MaCain, Sr. John C. 1965. The Caprellidae (Crustacea: Amphipoda) of Virginia. Chesapeake Sci., Vol. 6, No. 3, pp. 190-196. 
Sando, H. 1946. Faunal list of the Zostera marina region at Kugurizaka coastal waters, Aomori Bay. Bull. Mar. Biol. Sta. Asamushi, Tohoku Univ., Vol. 12, No. 1, pp. 27-35. (Caprellids identified by UTINOMI: 31 )

Schellenberg, A. 1938. Litorale Amphipoden des tropischen Pazifiks. Kungl. Svenska Vetenskapsakad. Handl., Ser. 3, Vol. 16, No. 6, pp. 1-105.

Stebing, T.R.R. 1888. Report on the Amphipoda collected by H.M.S. "Challenger". Sci. Rep. Voy. Challenger. Zool., Vol. 29, Second half of Text, pp. 873-1737; Plate, i-xiii, pls. I-CCX. London.

Steinberg, J.E. and E.C. Dougherty 1957. The skeleton shrimps (Crustacea: Caprellidae) of the Gulf of Mexico. Tulane Studies Zool., Vol. 5, No. 11, pp. 267-288.

Sundara Raj, B. 1927. Amphipoda Caprellidae (Laemodipoda) in the Littoral fauna of Krusadai Island. Bull. Madras Govt. Mus., New series-Nat. Hist. Sect., Vol. 1, No. 1, pp. 125-128, pls. 15-18.

Utinomi, H. 1943a. Caprellids obtained in Onagawa Bay, northern Japan. Sci. Rep. Tohoku Univ, Ser, 4, Biol., Vol. 17, No. 3, pp. 271-279.

- 1943b. Report of the biological survey. 37. Caprellids from Asamushi. Ibid., Vol. 17, No. 3, pp. 281-287.

1943c. The fauna of Akkeshi Bay. XIII. Caprellidea. J. Fac. Sci., Hokkaido Univ., Ser. 6, Zool., Vol. 8, No. 3, pp. 283-300.

1947. Caprellidae of Japan and adjacent waters. Seibutu, Suppl. No. 1, pp. 68-82. (In Japanese)

1964. Caprellidea. Fauna and flora of the seas around the Amakusa Mar. Biol. Lab., Part V.

Amphipod Crustacea (ed. T. KIKUchI), pp. 11-15, pls. I-III. (In Japanese)

- 1968. Epibenthic or planktonic caprellids from the environs of Tanabe Bay (Amphipoda: Caprellidae). Publ. Seto Mar. Biol. Lab., Vol. 16, No. 4, pp. 281-289.

Vassilenko, S.V. 1967. Fauna of Caprellidae (Amphipoda) of the Possjet Bay (the Sea of Japan) and some data on their ecology. Issledovanija Fauny Morei, V (XIII), Biotzenozy Zalika Possjet Japanskovo Morja, pp. 196-229. (In Russian) 